Int. J. Dev. Biol. 63: 461-471 (2019)

https://doi.org/10.1387/ijdb.190236jk

\title{
The endocytic pathways of Dictyostelium discoideum
}

\author{
JAMES H. VINES and JASON S. KING* \\ Department of Biomedical Sciences, University of Sheffield, Sheffield, UK
}

\begin{abstract}
The formation and processing of vesicles from the cell surface serves many important cellular functions ranging from nutrient acquisition to regulating the turnover of membrane components and signalling. In this article, we summarise the endocytic pathways of the social amoeba Dictyostelium from the clathrin-dependent and independent internalisation of surface components to the engulfment of bacteria or fluid by phagocytosis and macropinocytosis respectively. Due to similarities with the professional phagocytes of the mammalian immune system Dictyostelium has been extensively used to investigate the complex remodelling and trafficking events that occur as phagosomes and macropinosomes transit through the cell. Here we discuss what is known about this maturation process in order to kill any potential pathogens and obtain nutrients for growth. Finally, we aim to put these studies in evolutionary context and highlight some of the many questions that remain in our understanding of these complex and important pathways.
\end{abstract}

KEY WORDS: Clathrin, macropinocytosis, phagocytosis, Dictyostelium, phosphoinositide, endocytosis

\section{The different types and roles of endocytosis}

Endocytosis is a collective term, which refers to several different mechanisms of internalisation but can be divided into two main sub-categories based on the size of the vesicles formed: micro- and macro-endocytosis (Fig. 1). The best understood microendocytic pathway is that mediated by the protein clathrin, known as clathrinmediated endocytosis (CME). Clathrin is a structural protein, which self-assembles to form a lattice shell around vesicles as they invaginate from the cell surface. This clathrin coat binds to adaptor proteins which recruit specific cargo proteins such as activated receptors, allowing them to be selectively internalised. More recently, clathrin-independent microendocytic pathways have also been identified, such as caveolin-associated endocytosis, which has additional functions in regulating membrane tension (Sinha et al., 2011). Microendocytic pathways therefore primarily act as mechanisms to regulate the cell surface and regulate responses to extracellular signals.

In contrast, the main purpose of macroendocytic pathways is to internalise extracellular components, such as the surrounding fluid or particulate matter like microbes, dead cells or debris. The engulfment of both fluid and particles is achieved by mechanisticallyrelated pathways known as macropinocytosis and phagocytosis respectively. In contrast to clathrin-mediated endosomes, which form by invagination of the plasma membrane, macropinosomes and most types of phagosomes are formed by specialised actinbased protrusions (Fig. 1). Whilst non-phagocytic cells are still able to take up fluid, this is mainly through the functionally-distinct (CLIC)/ GEEC pathway (CLathrin-Independent Carriers /Glycosylophosphatidylinositol-anchored protein Enriched Compartment) mediated by elongated tubular invaginations of the plasma membrane (Mayor et al., 2014). Macropinocytosis and phagocytosis play important but specialised roles in diverse processes including nutrient acquisition, immune surveillance, defence against pathogens and the developmental clearance of dead cells (Bloomfield and Kay, 2016; Lim et al., 2017). Therefore, whilst CME is ubiquitous, macroendocytosis is normally performed by specific cells in metazoa, such as those of the immune system.

The different functions of micro- and macro-endocytosis are apparent from the relative size of the vesicles formed. Clathrinmediated endosomes are small and uniform, averaging $100 \mathrm{~nm}$ in diameter. This ensures a high surface area:volume ratio and therefore efficient membrane internalisation, whilst taking up relatively little fluid. Macropinosomes are larger and more heterogeneous in size, (between 200 and 2,000 $\mathrm{nm}$ diameter) and therefore take up substantially more fluid whilst minimising turnover of the plasma membrane. Additionally, whilst CME is selective, macropinosomes and phagosomes have no coats or adaptor proteins and therefore largely internalise surface constituents non-specifically. CME is

Abbreviations used in this paper: CLIC, clathrin-independent carriers; GME, clathrin mediated endocytosis; GEEC glycosylophosphatidylinositol-anchored protein enriched compartment; PIP, phosphatidyl inositol phosphate; SNARE, snap receptor; WASH, WASP and SCAR homologue.

*Address correspondence to: Jason S. King. Department of Biomedical Sciences, University of Sheffield, Sheffield, UK.
E-mail: Jason.king@sheffield.ac.uk

Submitted: 18 June, 2019; Accepted: 23 July, 2019.

ISSN: Online 1696-3547, Print 0214-6282 


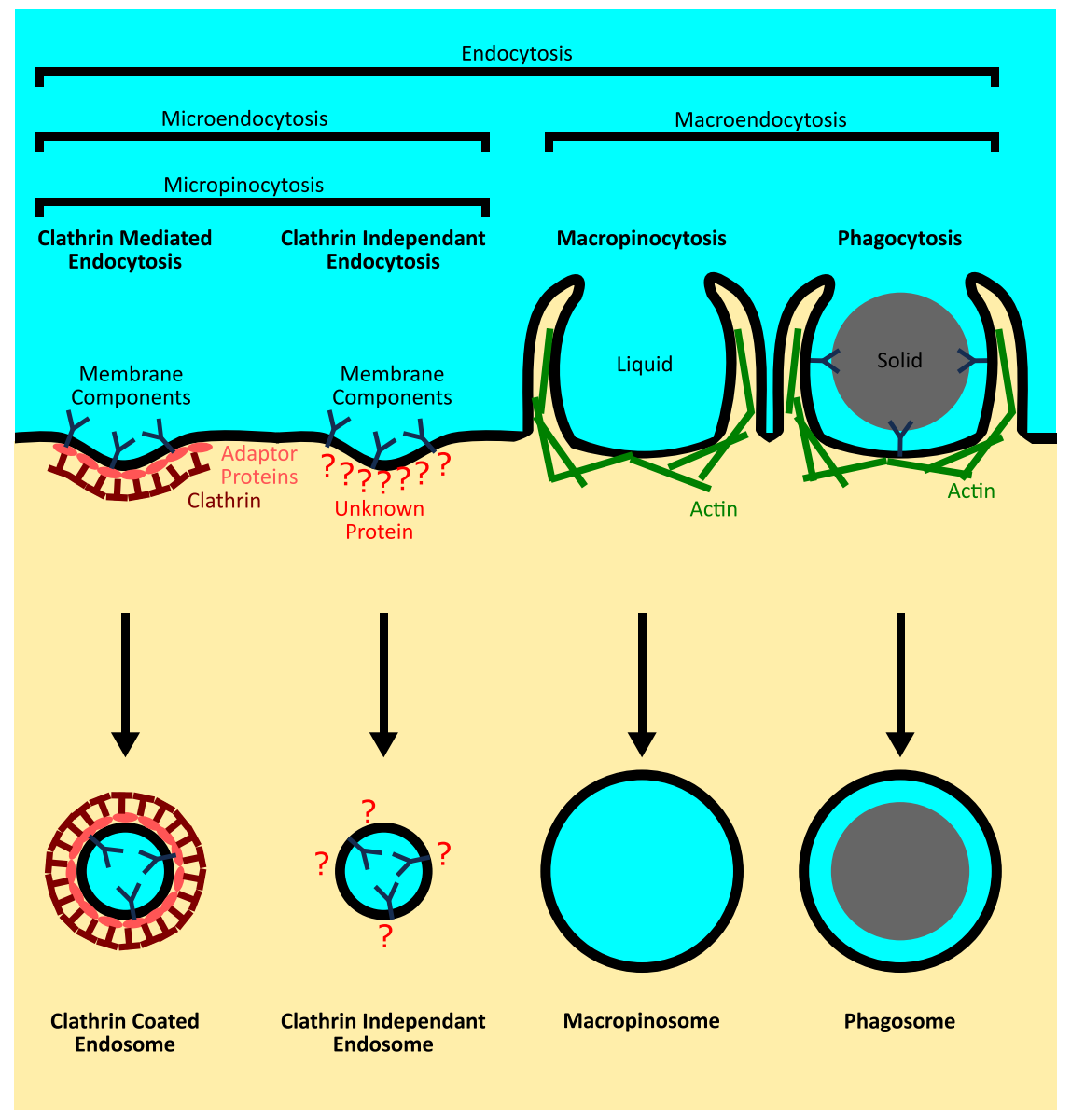

Fig. 1.The endocytic pathways in Dictyostelium. From left to right: (1) In clathrin mediated endocytosis, selected membrane components to be internalized bind to adaptor proteins, which in turn bind intracellular clathrin. This creates an intracellular coat of clathrin and invagination of the plasma membrane, resulting in the formation of a small intracellular vesicle known as a clathrin coated endosome. (2) clathrin-independent endocytosis, whereby membrane components are taken up in the absence of clathrin and independently from macroendocytosis. The mechanism by which this is achieved is unknown (3) In macropinocytosis, extracellular fluid is taken up in large cup formed from spontaneous actin-based protrusions at the cell surface. This forms a large intracellular vesicle. (4) In phagocytosis, an extracellular particle (i.e. bacteria, yeast or latex bead) is taken up upon binding and activation of cell surface receptors, which stimulates actin polymerisation in a similar manner to a macropinocytic cup. This forms a large intracellular endosome known as a phagosome.

therefore optimised for specific uptake of membrane components, whereas macropinocytosis is better adapted to take up extracellular material using the least possible membrane.

The importance of endocytosis and intracellular vesicle trafficking is highlighted by the prominence of mutations in these pathways associated with human diseases (Aridor and Hannan, 2002; Howell et al., 2006; Mellman and Yarden, 2013; Wang et al., 2014). Over many years of research a broad range of experimental systems have been used to dissect various aspects of endocytosis, most notably the identification of many important trafficking proteins discovered by genetic screens performed in yeast (reviewed in (Weinberg and Drubin, 2012)). However, despite enormous progress, many questions remain. Each model organism has its own particular nuances, and it is essential that studies are interpreted within a broader evolutionary context. In this article we focus on the endocytic pathways of the social amoeba Dictyostelium discoideum, which has been extensively used as a model to study many aspects of cell biology, and made a significant contribution to our understanding of intracellular trafficking.

\section{Dictyostelium as a model organism}

Dictyostelium discoideum is an amoeba that lives in soil and leaf-litter. When nutrients are plentiful, Dictyostelium grow as single cells by binary fission, preying on environmental bacteria for food (Fig. 2). During this life cycle the amoebae are professional phagocytes and, in comparison to mammalian cells, are most similar to the phagocytes of the innate immune system, such as macrophages and neutrophils. Whilst the densely packed, static tissues in multicellular organisms means most cells are not phagocytic, the engulfment machinery and mechanisms used by specialists to kill and digest captured microbes are highly conserved across evolution (Boulais et al., 2010). Phagocytosis therefore first evolved to feed our distant phagotrophic single-celled ancestors such as Dictyostelium, before being selectively suppressed in metazoan tissues.

Many studies have therefore taken advantage of the experimental benefits of Dictyostelium to model immune cell functions such as bacterial engulfment and killing (Bozzaro and Eichinger, 2011; Dunn et al., 2017).

When food is scarce however, Dictyostelium initiate a multicellular developmental cycle (Fig. 2). This involves communication between large numbers of amoebae to form aggregates of over 100,000 cells. These then differentiate into multiple different cell types to initially form a slug, which migrates towards heat and light to reach the soil surface. Remarkably, whilst phagocytosis is suppressed in most cells within the slug, a few hundred retain this capacity and appear to play the role of patrolling immune cells (Chen et al., 2007; Zhang et al., 2016). These cells, known as sentinel cells, are even able to eject extracelIular DNA traps to capture and kill pathogens, highly reminiscent of the Neutrophil Extracellular Traps (NET's) important for innate immunity in mammals (Papayannopoulos, 2018).

After the slug stage, the cells differentiate further to generate a fruiting body consisting of a sporehead, which is held aloft by a rigid stem of stalk cells. This structure aids dispersal, whereby the dormant spores can be scattered to find new sources of food whilst the stalk cells are sacrificed for the greater good (Strassmann et al., 2000). This is a complex process, dependent on both inter- and intra-cellular signalling and has thus been the subject of intense research for over 70 years (Loomis, 2014).

The varied life of Dictyostelium has made it an attractive organism to investigate many cellular processes. This is aided by a small haploid genome, making it amenable to genetic manipulation and often lacking the redundancy that can be problematic in higher 


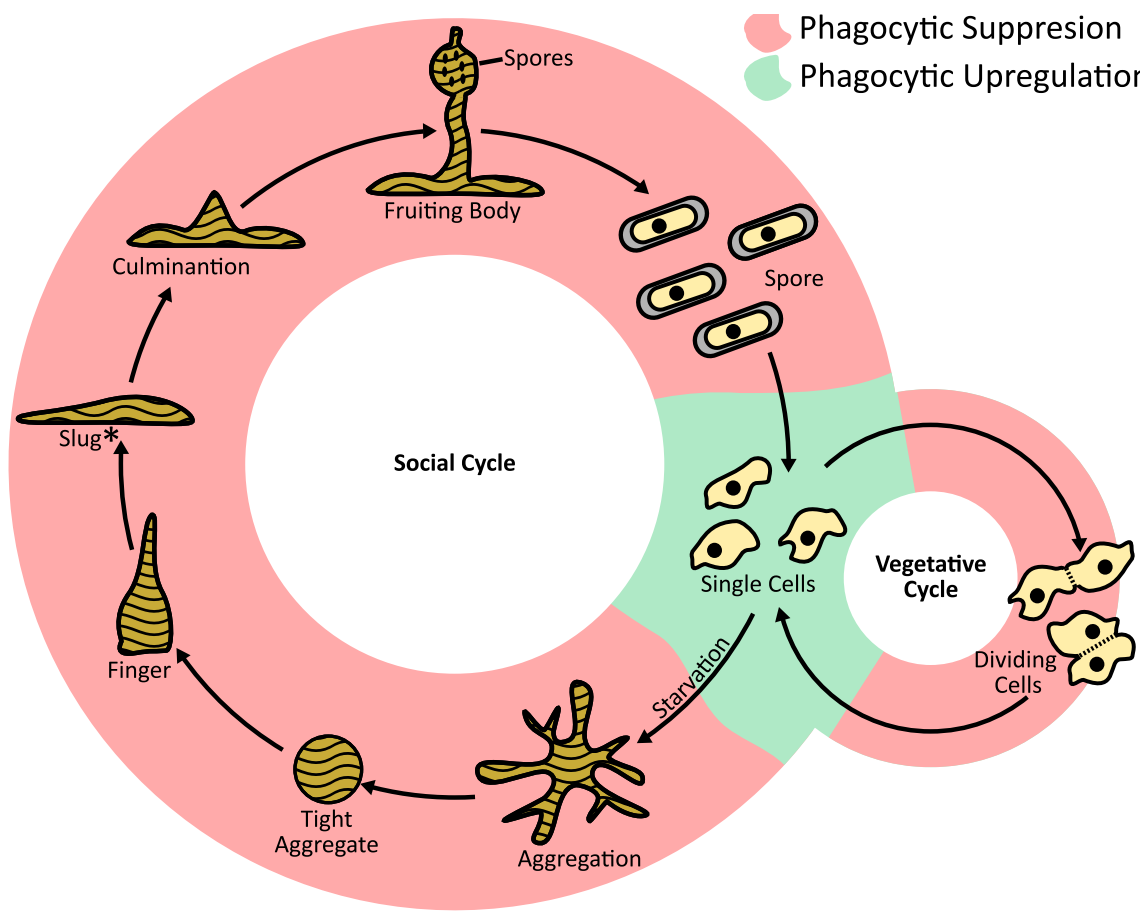

Fig. 2. Endocytosis throughout the Dictyostelium life cycles. In nutrient-replete conditions, Dictyostelium will grow in the vegetative cycle where they feed through phagocytosis and macropinocytosis, as highlight by the green background. Upon starvation, macroendocytosis is largely suppressed and large numbers of cells aggregate by chemotaxis and undergo differentiation to form a multicellular structure consisting of $>100,000$ cells. The purpose of this structure is to aid the distribution of spores to a more nutrient rich environment. Both chemotaxis and development are dependent on clathrin-mediated endocytosis.

eukaryotes (Eichinger et al., 2005). Although the amoebozoa diverged from the animal lineage before fungi and after plants, the Dictyostelium genome appears to have retained much of the ancestral eukaryotic genome. Dictyostelium therefore possesses a number of genes that have been subsequently lost in other lineages, most notably in the contracted genome of Saccharomyces cerevisiae (Hirst et al., 2014; King, 2012; O'Malley et al., 2016; Roelofs and Van Haastert, 2001).

Simple genetic manipulation coupled with the ability to grow large numbers of isogenic cells for biochemical studies and amenability for fluorescence microscopy, has made Dictyostelium a useful system for many trafficking studies. Below, we discuss what is known about the different forms of endocytosis performed by Dictyostelium, with a focus on phagocytosis and macropinocytosis, which have been the most extensively investigated.

\section{The endocytic pathways of Dictyostelium}

\section{Microendocytosis: clathrin dependent and independent}

Although the majority of studies have focused on the largescale endocytic pathways, Dictyostelium, like all eukaryotes, also use microendocytosis to internalise the plasma membrane and its constituents. Dictyostelium turnover their entire plasma membrane by microendocytosis every $\sim 10$ minutes (Aguado-Velasco and Bretscher, 1999), whereas the contribution from macropinocytosis is estimated to be 10-fold less (Aguado-Velasco and Bretscher, 1999; Buckley et al., 2016). Surprisingly, mutants lacking the clathrin heavy chain (chcA), which is essential for lattice formation are only reduced in their membrane turnover by $25 \%$ (Aguado-Velasco and Bretscher, 1999; O'Halloran and Anderson, 1992; Ruscetti et al., 1994). This is not due to upregulated macropinocytosis as $c h c A$ - cells also have significantly reduced fluid uptake, and clathrin-independent membrane internalisation is not aggravated by actin-depolymerising drugs (Neuhaus et al., 2002; O'Halloran and Anderson, 1992). Microendocytosis can therefore occur by a clathrin independent mechanism in Dictyostelium. How this is achieved is unknown and whilst the caveolin proteins are able to drive endosome formation in mammalian cells, they only evolved in metazoa and so are not present in Dictyostelium(Kirkham et al., 2008).

Whilst disruption of clathrin is not lethal, wildtype Dictyostelium cells have several hundred dynamic clathrin-coated pits on their surface at any one time, indicating that high levels of CME occur constitutively (Veltman et al., 2011). Clathrin mutants are also perturbed in a wide range of cellular processes including cytokinesis, cell migration, lysosomal sorting, secretion and osmoregulation (O'Halloran and Anderson, 1992; Ruscetti et al., 1994; Wessels et al., 2000). Clathrin mutants also have severe defects in development (O'Halloran and Anderson, 1992). Many of these defects can be explained by defective trafficking of cell surface receptors and consequent disruption of signal transduction. However, clathrin also plays a role in sorting events within the cell, such as sorting and budding from intracellular compartments like the trans-Golgi network. Therefore phenotypes such as defects in the biogenesis of lysosomes and the specialised contractile vacuole osmoregulatory network found in protists may be due to disruption of intracellular sorting rather than endocytosis per se (Lefkir et al., 2003; Poupon et al., 2008; Ruscetti et al., 1994).

\section{Phagocytosis}

During vegetative growth, Dictyostelium are extremely efficient phagocytes and are able to feed on a broad range of both Grampositive and Gram-negative bacteria. Phagocytosis is driven by the activation of cell surface receptors by binding to bacterial surface components. This can be mediated by a range of different receptors such as the Dictyosteliumorthologues of the mammalian $\beta$-integrins (Similar to Integrin Beta, SibA and SibC) (Cornillon et al., 2006) or the scavenger receptor LmpB (lysosomal membrane glycoprotein B) (Sattler et al., 2018). Recently it was also shown that the same G-protein coupled receptor that drives chemotaxis to bacterially-secreted folate can also initiate phagocytosis by binding to lipopolysaccharides on the bacterial surface (Pan et al., 2018).

After engulfment, phagosomes rapidly mature to generate an internal antimicrobial environment and kill the captured bacteria. This is achieved by multiple, parallel killing mechanisms involving acidification, digestion, metal ions and oxidative attack and is essential to prevent infection from potential pathogens (described in more detail later). After killing, bacteria are digested and nutrients 
extracted to support growth of the amoebae, whilst any indigestible material is subsequently expelled.

As phagosome trafficking is often manipulated by pathogens to facilitate their intracellular survival, Dictyostelium have proven to be a useful model host to study a wide range of pathogenic bacteria including Mycobacterium marinum (a model for Tuberculosis), Legionella pneumophila, Klebsiella pneumoniae, Francisella noatunensis and Listeria monocytogenes (Reviewed in (Bozzaro and Eichinger, 2011; Dunn et al., 2017)). Although environmental isolates of Dictyostelium are strictly bacterivorous and cannot generate phagocytic cups large enough to engulf fungi, axenic laboratory strains can ingest larger organisms (Bloomfield et al., 2015). These strains have therefore also been used to study fungal infections (Hillmann et al., 2015; Koller et al., 2016; Watkins et al., 2018). As many pathogens also have an environmental niche, avoiding predation by amoebae such as Dictyostelium or the more common water amoeba Acanthamoeba castellanii has been proposed to be an important evolutionary driver of virulence traits - further validating the use of these organisms to study host-pathogen interactions (Casadevall et al., 2019; Molmeret et al., 2005).

\section{Macropinocytosis}

Consistent with a shared evolutionary origin for phagocytosis and macropinocytosis, Dictyostelium also constitutively take up fluid from their environment and can use it for food (Kay et al., 2019; King and Kay, 2019). Whilst both macropinocytosis and phagocytosis can be used to feed, they were recently shown to be inversely regulated, with macropinocytosis suppressed in the presence of bacteria and upregulated when bacteria were removed (Williams and Kay, 2018). Dictyostelium therefore adapt to the nutrient source available, although they prefer bacteria - a richer source of nutrients - over a liquid diet.

Feeding by macropinocytosis is important because like most protists and unlike most metazoan cells, Dictyostelium do not directly transport nutrients across the plasma membrane into the cytosol. This is most likely because living free in the environment inevitably exposes amoebae to the huge diversity of chemicals generated by the soil microbiota, including many potentially harmful molecules. This problem is circumvented by centralised nutrient extraction and detoxification in metazoa, but organisms such as Dictyostelium must attempt to control the absorption of extracellular molecules by first confining them within vesicles. Recently it has become clear that this original role for macropinocytosis in acquiring nutrients still occurs in mammals, and is used by cancer cells to enable the use of extracellular proteins as an additional food source to support their rapid growth (Commisso et al., 2013).

Whilst Dictyostelium can use macropinocytosis to feed, the amount of fluid taken up by wild-type environmental isolates is insufficient to support growth in liquid media unless heavily supplemented with protein (i.e. 10\% fetal calf serum (FCS)(Bloomfield et al., 2015)). However, after prolonged incubation or mutagenesis, mutants can be selected that form much larger cups and engulf enough nutrients to grow (Sussman and Sussman, 1967; Watts and Ashworth, 1970). The ability to grow pure cultures of cells in the absence of bacteria has advantages for both genetic and biochemical studies. Therefore axenic mutant strains (known as Ax2-4) were widely adopted by the Dictyostelium community since their isolation (Watts and Ashworth, 1970). Surprisingly, the key mutation that enables axenic growth was only recently identified as loss of function of the Dictyostelium orthologue of neurofibromin (NF1) (Bloomfield et al., 2015). NF1 is a GTPase Activating Protein (GAP) that deactivates the small GTPase known as Ras. Ras is a key regulator of macropinosome formation in both Dictyostelium and mammals (Bar-Sagi and Feramisco, 1986). Disruption of Dictyostelium NF1 causes hyperactivation of Ras, increasing the size of the cup-shaped protrusions that generate macropinosomes and therefore the volume of fluid engulfed (Bloomfield et al., 2015). Importantly, this regulatory role in macropinocytosis and therefore inflammatory signalling was also recently confirmed in mouse macrophages (Ghoshal et al., 2019). Mutations in NF1 also cause the genetic condition Neurofibratomatosis type 1 in humans, resulting in tumours in the nervous system (Xu et al., 1990). Whether these two observations are causally linked remains to be determined, but the conserved role of NF1 emphasises how the mechanisms underlying macropinosome formation have been preserved across evolution.

The prominence of phagocytosis and macropinocytosis in Dictyostelium, combined with obvious parallels in the cell biology of amoebae and phagocytic cells of the immune system has meant that this is where the majority of endocytic studies have been focused in Dictyostelium. Indeed, the technical challenges faced in studies using mammalian macrophages and neutrophils have made Dictyostelium a valuable alternative experimental system to explore the basic mechanisms of engulfment, killing and digestion (Bozzaro and Eichinger, 2011). Engulfment is driven by the generation of actin-rich protrusions, sharing much of the same machinery used to drive cell migration. Macropinosome formation is particularly interesting, as the cups are able to spontaneously self-organise in the absence of any spatial or physical signals from a particulate template. This is described elsewhere, including in this issue (Buckley and King, 2017; Kay et al., 2019; Williams et al., 2019). The focus of this review will instead be on the maturation pathway of these compartments in Dictyostelium from the moment the phagosomes and macropinosomes have formed, until their eventual resolution.

\section{The trafficking of macropinosomes and phagosomes}

Phagocytosis and macropinocytosis co-evolved as feeding mechanisms in early eukaryotes (King and Kay, 2019). Therefore the mechanisms used to process and extract nutrients from the internalised fluid or bacteria are very similar. Whether the activation of membrane receptors during phagocytosis affects subsequent maturation is unclear. However, as Dictyostelium are clearly able to discriminate between different bacteria (Nasser et al., 2013) it is possible that phagosomes generate a more antimicrobial environment than macropinosomes.

Broadly, maturation can be divided into four distinct stages: (1) nascent recycling events, (2) early maturation (3) late maturation and (4) expulsion of indigestible waste (Figs. 3,4). Within each stage a variety of fusion and fission events occur, principally regulated through inositol phospholipids within the vesicle membrane, and Rab-family small GTPases present on the vesicle surface. Both of these act to mark different endocytic compartments and recruit specific effectors as they progress through the maturation pathway. As progression occurs, the luminal contents of both macropinosomes and phagosomes become acidified and digested to liberate nutrients before the final stage where any indigestible 

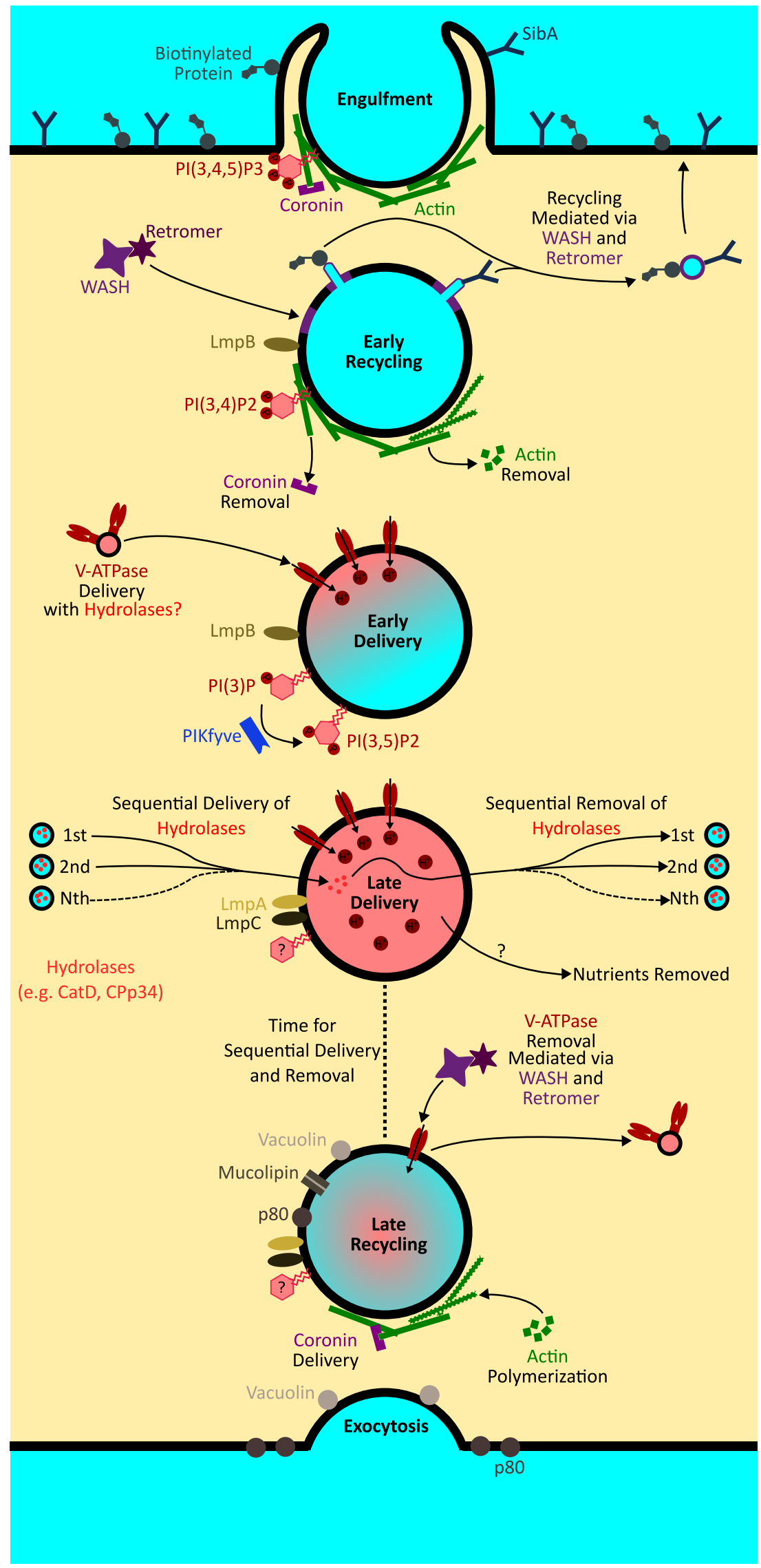

fragments are expelled from the cell. In $D$. discoideum this complete process takes around an hour. This pathway is highly conserved with mammalian leukocytes, with the exception of the final expulsion stage as both macrophages and neutrophils can retain engulfed material indefinitely, presumably to prevent an inflammatory response (Bai et al., 2015).

\section{The nascent macropinosome/ phagosome}

Nascent macropinosomes and phagosomes are those which have just formed and separated from the plasma membrane. How the point of scission is detected is unknown, but the vesicles formed will be large, with a $\mathrm{pH}$ equal to that of their extracellular environment and a membrane consisting primarily of proteins and lipids found in the plasma membrane. Initially they are surrounded by actin filaments, which are required for the cup formation and sealing process (Rupper et al., 2001). These filaments dissociate within 30-60 seconds following cup closure (Clarke et al., 2010; Rupper et al., 2001) along with actin associated proteins, such as coronin (Lu and Clarke, 2005; Maniak et al., 1995). This process coincides with the movement of the nascent macropinosome/phagosome away from the plasma membrane and the initiation of subsequent membrane rearrangement events.

The inositol phospholipid (PIP) content of the membrane also changes during this time-period. PIPs are a family of lipids whereby the inositol sugar head-group can be phosphorylated at any of three

Fig. 3. Macropinosome and phagosome maturation in Dictyostelium. The cartoon shows the progress of macroendosomes as they mature. Upon engulfment, the PI $(3,4) P 2$ positive nascent vesicle is surrounded by actin which is rapidly removed. In an early recycling phase, plasma membrane proteins are rapidly recycled back to the plasma membrane by the WASH and retromer complexes. During this process, the compartment accumulates PI(3) $P$, and an early delivery phase also begins as the V-ATPase is delivered on small acidic vesicles. V-ATPase activity causes acidification of the vesicle lumen (represents by red colouring), and over time $P I(3) P$ is converted to $P I(3,5)$ $P 2$ by the activity of PIKfyve. In a later delivery phase, when the lumen is acidified, hydrolases such as CatD and CP-p34 are sequentially delivered over an extended, digestive period. At this time, nutrients are presumably removed from the lumen via an unknown mechanism. Finally, after digestion is complete, the macroendosome is prepared for exocytosis in a late recycling phase. Here, WASH-stimulated actin re-forms around the compartment to retrieve the V-ATPase and form a neutral post-lysosome. The retromer complex is also present and potentially plays a role in hydrolase retrieval. Other important proteins such as vacuolin and mucolipin also accumulate on this late compartment, although are most probably retrieved before exocytosis, unlike $p 80$ which is present during exocytosis and can be seen in high concentrations at the plasma membrane immediately after. 


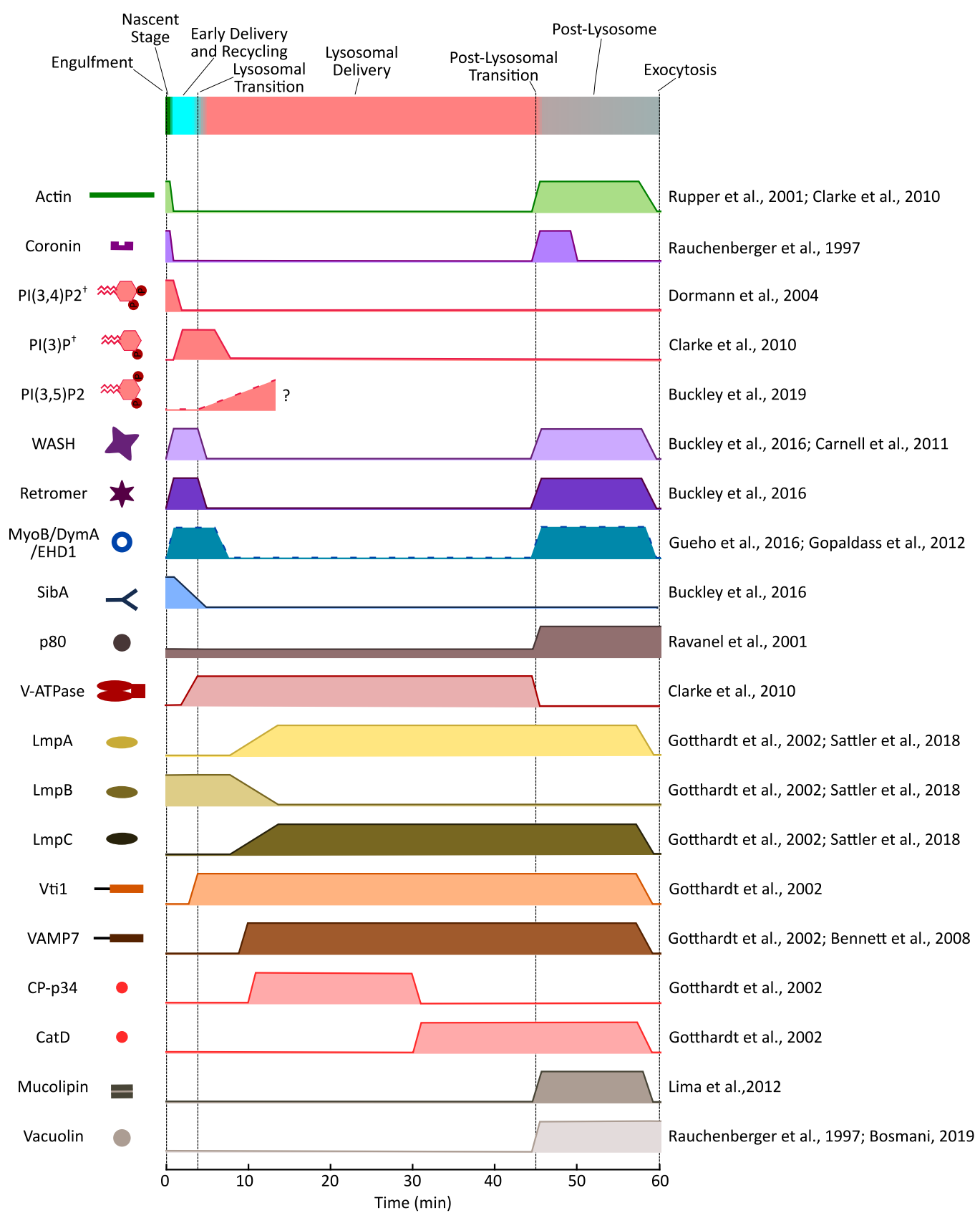

Fig. 4. Timings of components of phagosome and macropinosome maturation in Dictyostelium. Each line represents the dynamics of the components (protein or lipid) covered by this review over a 60-minute maturation event. When the line of the time-courses is high, the respective component is at/on/in the endosome at this time-point. When the line of the time-course is low, the component is not present. This diagram has been pieced together from the existing literature, combining both microscopy and biochemical data. We have made the assumption that phagosome and macropinosome maturation are comparable and integrated data from studies of both pathways. The large majority of the studies cited support this, with the exception of minor differences in phosphoinositide dynamics discussed in the main text. It should be noted that in general, biochemical analysis of purified phagosomes often indicates slower maturation than that observed by live-cell imaging, with maturation occuring over an almost 3 hour period (Buckley et al., 2016; Gopaldass et al., 2012; Gotthardt et al., 2002a). Microscopy studies in contrast, indicate exocytosis of yeast and bead-containing phagosomes, as well as macropinosomes occurs at around 60-90 minutes after engulfment (Clarke et al., 2010; Lima et al., 2012; Ravane/ et al., 2001; Watkins et al., 2018). We have consolidated and corollated data from both techniques to an "average" 60-minute transit. With this in mind, this figure is best viewed in the context of our review as a whole and combined with the references provided for each individual component. " $t$ " indicates that retrieval phase is known to be longer in phagosomes containing yeast. Time courses with dashed lines indicate an even greater level of uncertainty. positions. The different phosphorylation states can be interconverted by a family of PIP kinases and phosphatases to generate seven different forms of the lipid. Each PIP is able to recruit different target proteins, resulting in an elegant system to identify different membranes and regulate endocytic trafficking (Bohdanowicz and Grinstein, 2013). Both macropinosome and phagosome membranes initially contain high levels of $\mathrm{PI}(3,4) \mathrm{P}_{2}$. $\mathrm{PI}(3,4) \mathrm{P}_{2}$ is generated by the rapid de-phosphorylation of $\mathrm{PI}(3,4,5) \mathrm{P}_{3}$ by the $\mathrm{PI}-5$ phosphatase called Oculocerebrorenal syndrome of Lowe (OCRL), during and immediately following cup closure (Dormann et al., 2004; Li et al., 2018; Loovers et al., 2007; Luscher et al., 2019). On phagosomal membranes $\mathrm{PI}(3,4) \mathrm{P}_{2}$ content peaks immediately following cup closure and is gradually lost over time (Dormann et al., 2004).
There are however conflicting reports of how long $\mathrm{PI}(3,4) \mathrm{P}_{2}$ is retained. Studies following phagocytosed yeast show that $\mathrm{PI}(3,4)$ $\mathrm{P}_{2}$ is only transiently present on the phagosome, between 60 and 120 seconds post-engulfment (Dormann et al., 2004; Giorgione and Clarke, 2008). In contrast, latex-bead containing phagosomes maintain $\mathrm{PI}(3,4) \mathrm{P}_{2}$ much longer - upwards of 360 seconds suggesting that the pathways regulating phagosomal maturation may be cargo-dependent (Giorgione and Clarke, 2008).

\section{Early recycling events}

One of the first key events in maturation is the recycling of plasma membrane components back to the cell surface. Several 
studies have shown that cell surface proteins are non-specifically internalised on both phagosomes and macropinosomes, but rapidly removed following engulfment (Buckley et al., 2016; Gotthardt et al., 2002b; Ravanel et al., 2001). This appears to occur over 2 phases, with an early myoB-independent phase followed by slower myoB-dependent recycling (Neuhaus and Soldati, 2000). Although the majority of proteins appear to be internalised non-specifically, there is also evidence that a subset can be specifically excluded from cups, although how this might be achieved is not known (Mercanti et al., 2006).

As the contents of macroendosomes are destined for degradation the rescue of cell surface components before their digestion is important for continued cell function. This is achieved by the combined action of sorting and recycling complexes. One such complex is the WASP and SCAR Homolog (WASH) complex, which is recruited to nascent macropinosomes and phagosomes in both D. discoideumand mammalian macrophages immediately following cup closure (Buckley et al., 2016). The WASH complex is able to generate patches of polymerised actin on the surface of vesicles via activation of the Arp2/3 complex (Derivery et al., 2009; Gomez and Billadeau, 2009). WASH enables the formation of actin-rich subdomains, which can both sequester specific proteins, as well as aid the formation of tubules and removal of the membrane. This is assisted by a direct interaction between the FAM21 subunit of the WASH complex and the vacuolar protein sorting-35 (VPS35) subunit of the retromer sorting complex (RSC), known to promote recycling (Jia et al., 2012). This is a general mechanism, and in recent years, studies in mammalian cells have shown WASH and the RSC mediate sorting from several different endosomal compartments (Seaman, 2012).

In D. discoideum, the WASH and retromer complexes co-localise on nascent phagosomes and macropinosomes, and disruption of WASH causes defects in the retrieval of surface proteins (Buckley et al., 2016). In the absence of this step, levels of surface proteins such as the Sib integrin-like receptors important for both substrate adhesion and phagocytosis are severely depleted (Buckley et al., 2016). Consequently, the phagocytosis efficiency of WASH-null cells is significantly reduced, demonstrating the importance of early surface protein retrieval in maintaining cellular functions.

Class I non-muscle myosins have also been shown to be important for early recycling events. Myosin IB heavy chain (MyoB) has also been identified as localising to nascent phagosomes, and disruption of both myosin I isoforms known as myosin IA heavy chain (MyoA) and MyoB or treatment with the myosin I inhibitor, butanedione monoxime, results in a build-up of cell surface proteins on intracellular compartments (Neuhaus and Soldati, 2000). How myosin I contributes to recycling mechanistically, or interacts with the WASH/Retromer complexes is yet to be determined. An additional class I myosin, myoK is also involved during early maturation, but plays a distinct role in regulating the association and delivery of ER components to the phagosome, although the functional significance of ER delivery is unclear (Dieckmann et al., 2012).

Another element important in early recycling from phagosomes and macropinosomes is the machinery to mediate the final stages of membrane scission as vesicles pinch off from endosomes (Gopaldass et al., 2012). The most well understood of these is the large GTPase dynamin, necessary for pinching off clathrin-coated vesicles from the plasma membrane and scission of vesicles from elongated endosomal tubules in mammalian cells and yeast
(Ferguson and De Camilli, 2012). Disruption of the Dictyostelium dynamin orthologue DymA disrupts multiple membrane scission events making it problematic to differentiate between direct and indirect roles (Wienke et al., 1999). Nonetheless, DymA localises to phagosomes during the early recycling phase and $D y m A$ mutants have very slow acidification and reduced proteolysis rates in later stages of maturation (Gopaldass et al., 2012).

Recently it was also shown that the Dictyostelium orthologue of EHD (Eps15 homology domain containing protein) is also recruited very early to phagosomes (Gueho et al., 2016). EHD proteins are structurally and functionally related to dynamin. Dictyostelium EHD and DymA physically interact and are recruited to the nascent phagosome simultaneously, but independently (Gueho et al., 2016). In mammals, EHD1 has been shown to regulate retromer-mediated trafficking (Zhang et al., 2012). Whilst disruption of DymA or EHD both result in hyper-tubulation of endosomal compartments, they appear to play functionally independent roles in phagosome maturation as in contrast to DymA mutants, EHD knockout phagosomes acidify more rapidly (Gueho et al., 2016).

Whilst it is easy to imagine a role for dynamin and EHD in the scission of recycling vesicles from nascent phagosomes and macropinosomes, this is yet to be directly tested. As WASH and the retromer are only present for the first 2-3 minutes following engulfment, but DymA and EHD remain for as long as 30 minutes, there are also likely to be a number of additional trafficking steps regulated by this membrane cleavage machinery (Buckley et al., 2016; Gueho et al., 2016).

\section{Early delivery events}

Following internalisation, and somewhat overlapping with early recycling, macroendosomes then undergo various fusions to deliver the digestive, acidification and killing machinery. This is often referred to as early maturation and occurs within the first 10 minutes post-engulfment. During this period phagosomes and macropinosomes are marked by the lipid $\mathrm{PI}(3) \mathrm{P}$ (Buckley et al., 2019; Clarke et al., 2010). Although it has not been confirmed in Dictyostelium, in mammalian cells this is generated by activation of the class III PI-3 kinase by Rab5 (Christoforidis et al., 1999b; Vieira et al., 2001).

$\mathrm{PI}(3) \mathrm{P}$ is not identifiable on the nascent phagosomes/macropinosome while it is still surrounded by actin, but appears almost immediately after internalisation (Clarke et al., 2010). PI(3)P is lost gradually from early phagosomes containing bacteria over the next six minutes (Clarke et al., 2010) and similar dynamics are also observed in macropinosomes (Clarke et al., 2010; King and Kay, 2019). In contrast, engulfed yeast retain PI(3)P much longer, again indicating cargo-dependent signalling dynamics (our unpublished observations and (Clarke et al., 2010)).

In mammalian cells, the best known Rab5/PI(3)P effector is EEA1 (Early Endosomal Autoantigen 1), which can lead to endosomal docking and fusion in collaboration with SNARE (Soluble NSF attachment Protein Receptor) membrane fusion complexes (Christoforidis et al., 1999a; Simonsen et al., 1998). Whilst Dictyostelium Rab5 has not been studied in detail, and there is no obvious EEA1 orthologue the presence of $\mathrm{PI}(3) \mathrm{P}$ coincides with the fusion of several different compartments with phagosomes and macropinosomes. The role for $\mathrm{PI}(3) \mathrm{P}$ in the fusion of endosomal compartments and delivery of maturation components is therefore 
likely to be conserved.

SNAREs are membrane bound proteins present in all eukaryotic cells, which function to fuse intracellular compartments. Fusion occurs when one vesicle-SNARE forms a complex with two or three specific target-SNAREs to form an alpha helix coiled-coil bundle (reviewed in (Hong, 2005)). The first target-SNARE found in Dictyostelium was the orthologue of syntaxin 7, required for endosome-endosome fusion (Bogdanovic et al., 2002). In complex with its co-target SNARES, syntaxin 8 and Vti1, syntaxin 7 is able to bind to a single vesicle-SNARE called VAMP7. Binding facilitates the fusion of the two respective compartments. VAMP7-GFP labels all $D$. discoideum early endocytic compartments, suggesting that these SNAREs mediate most early fusion events (Bennett et al., 2008). However, the precise fusions in which these SNAREs are used are not well characterised.

One of the best characterised complexes delivered to the phagosome and macropinosome within its early stages is the vacuolar ATPase (V-ATPase) (Clarke et al., 2002; Gotthardt et al., 2002b). The V-ATPase is responsible for the translocation of protons across membranes and consequently it is the key component leading to lumen acidification. The V-ATPase complex is formed of multiple subunits, including the large $100 \mathrm{kDa}$ transmembrane subunit VatM. Studies following the trafficking of GFP-tagged VatM showed that it is delivered to early phagosomes and macropinosomes over the first 1 to 2 minutes after engulfment (Clarke et al., 2002; Clarke et al., 2010). Delivery occurs via small GFP-VatM-positive acidic vesicles, which cluster around the early phagosome before fusing (Clarke et al., 2002). These pre-existing, acidic compartments stem from the endosomal system as they can be labelled with the endosomal dye TRITC-dextran, which becomes visible in the lumen of the phagosome within 3 to 4 minutes post engulfment (Clarke et al., 2002; Clarke et al., 2010).

V-ATPase delivery coincides with the rapid acidification of macroendosomes, which begins around 60 seconds after engulfment. VatM concentrations increase until a peak around 4 minutes after cup closure, coinciding with the end of the WASH/retromer recycling phase (Buckley et al., 2016). Luminal pH continues to drop to a low of $\mathrm{pH} 3.5$ over about 10 minutes, where it is maintained for a further 30 minutes to allow for digestion (Gopaldass et al., 2012). Whilst VatM is essential for cell viability, knock-down of the protein shows slow cell growth, reduced phagocytosis, and a mis-localisation of other V-ATPase subunits, including the catalytic subunit, VatA (Liu et al., 2002).

More recent studies have implicated PIKfyve, a PI-5 kinase, in the efficient delivery of V-ATPase (Buckley et al., 2019). PIKfyve catalyses the conversion of $\mathrm{PI}(3) \mathrm{P}$ to $\mathrm{PI}(3,5) \mathrm{P}_{2}$, and knockouts of PIKfyve have slower V-ATPase delivery to early phagosomes, and consequently are defective in acidification (Buckley et al., 2019). PIKfyve is also important for hydrolase delivery and proteolysis (see below). Cells lacking PIKfyve are therefore poor at killing engulfed bacteria and are thus highly susceptible to pathogens, such as Legionella pneumphila (Buckley et al., 2019). Despite this importance, the role of $\mathrm{PI}(3,5,) \mathrm{P}_{2}$ is poorly characterised, with a paucity of known effector proteins.

\section{Delivery of lysosomal enzymes}

As maturation progresses, the lysosomal enzymes important for digestion are delivered to the phagosome/macropinosome. Acid hydrolyses are some of the best characterised proteins known to be delivered during this stage and depend on the low $\mathrm{pH}$ generated by the V-ATPase for activity. Contrary to a model whereby a lysosome containing the entire gamut of digestive enzymes and the V-ATPase deliver them to phagosomes all at once, imaging of lysosomal enzymes with different sugar modifications and proteomics of purified phagosomes both indicate multiple phases of delivery and retrieval throughout the 45 minute digestive period (Gotthardt et al., 2002b; Souza et al., 1997). For example, the cysteine protease CP-p34 is amongst the first hydrolases delivered, coinciding with delivery of the two Lysosomal Membrane Proteins LmpA and LmpC (Gotthardt et al., 2002b). This is subsequently followed by CP-p34 retrieval and delivery of cathepsin D (CatD), a second hydrolase, which is retained until just before exocytosis, along with LmpA and LmpC (Gotthardt et al., 2002b). How specific luminal enzymes are selectively trafficked is not known, and the reason for sequential delivery and retrieval is not entirely clear. However, it may be possible that digestion is more efficient if early hydrolases partially digest the luminal contents for later ones with different cleavage specificity.

\section{The post-lysosomal transition and exocytosis}

The final stage of maturation ends in the expulsion of indigestible luminal contents into the extracellular space. However, before this can happen, various proteins must be retrieved from the compartment, which at this stage is referred to as the post-lysosome. The transition from a digestive compartment to a post-lysosome is precipitated by retrieval of the V-ATPase and subsequent neutralisation. Over a three minute period, the V-ATPase is sequestered from the membrane into small vesicles and recycled (Clarke et al., 2010). The mammalian V-ATPase directly binds actin (Holliday et al., 2000; Vitavska et al., 2003), and although this interaction has not been confirmed in Dictyostelium, V-ATPase retrieval is dependent on actin polymerisation (Clarke et al., 2010). Surprisingly, this is mediated by a second, independent phase of WASH complex activity, which occurs 40-50 minutes after engulfment (Carnell et al., 2011). In the absence of WASH, phagosomes and macropinosomes never neutralise and cells have a complete block in exocytosis (Carnell et al., 2011). In WASH null cells, hydrolases also accumulate in this late compartment, blocking their recycling and delivery to nascent endosomes (King et al., 2013). Exocytosis, neutralisation and hydrolase retention are also all defective in cells expressing dominant-negative Rab7 (Buczynski et al., 1997). It is therefore likely that an additional mechanism to retrieve hydrolases before they are lost by exocytosis exists, potentially via the activity of the retromer, which is also present at this time (Buckley et al., 2016).

As the V-ATPase is removed the luminal $\mathrm{pH}$ neutralises and additional components are gained such as the putative copper transporter p80, which is commonly used to identify the postlysosomal compartment (Ravanel et al., 2001). The metal ion composition of post-lysosomes appears to be highly regulated as mucolipin-1, a calcium ion channel, is also specifically found on this compartment (Lima et al., 2012). Disruption of mucolipin results in decreased calcium within the post-lysosome and increased exocytosis, although how this is mediated by calcium is unclear (Lima et al., 2012). Another important late protein seems to be IvsB (Large Volume Sphere), a Dictyostelium homologue of the LYST/ Beige (Lysosomal Trafficking Regulator) protein which is important 
in endosomal fusion in mammals and mutated in Chediak-Higashi syndrome (Charette et al., 2007). In IVsB mutants the lysosome/ post-lysosomal transition is defective, resulting in decreased postlysosomal numbers and exocytosis (Charette et al., 2007).

Post-lysosomes also likely have unique lipid properties as they specifically accumulate the Dictyostelium orthologues of flotillin (known as the vacuolins) which partly reside in detergent-resistant lipid microdomains known as lipid rafts (Bosmani et al., 2019; Jenne et al., 1998; Rauchenberger et al., 1997). In mammalian cells, these microdomains are found on both the plasma membrane and endosomal compartment, where they function as platforms for signalling and recycling of specific cargoes (Stuermer and Plattner, 2015). Despite their predominantly post-lysosomal localisation, disruption of the vacuolin causes defects throughout the endocytic cycle, including faster maturation, defective recycling of membrane proteins and strong defects in phagocytosis (Bosmani et al., 2019). It is therefore likely that lipid-microdomain mediated sorting and recycling has pleiotropic functions throughout the Dictyostelium endocytic pathway.

\section{Conclusions and perspectives}

The studies described above demonstrate complex remodelling of endosomes throughout their transit through the cell. Multiple mechanisms are employed to retrieve and deliver both soluble and transmembrane components at specific points to achieve the orderly capture of extracellular nutrients whilst protecting the cell from environmental toxins, potential pathogens, or the accidental degradation of surface components. Much of this machinery is conserved throughout evolution and Dictyostelium has proven a useful model for the phagocytic cells of the human immune system.

Many questions still remain. For example, scission from the plasma membrane instigates the immediate start of maturation, but the events surrounding cup closure and the transition from formation to maturation are very poorly understood. Whilst macroendocytic transit follows a consistent maturation programme with defined transitions, how this is timed and translated into abrupt changes in vesicle identity is not known. There are also many mechanistic questions about how specific components are delivered and retrieved that will only be elucidated by future studies.

Importantly, Dictyostelium provides a highly accessible system to manipulate and dissect these pathways using both in vivo and biochemical techniques. As many recent studies have demonstrated, the ability to extend such investigations to interactions with potential pathogens has uncovered many fascinating aspects of the constant competition between phagocytes and their prey. Whilst new techniques such as CRISPR-Cas9 gene editing have opened up new possibilities to manipulate mammalian cells, the relative simplicity, reduced functional redundancy and ease of use mean there is still much we can learn from these humble amoebae.

\section{References}

AGUADO-VELASCO, C. and BRETSCHER, M. S. (1999). Circulation of the plasma membrane in Dictyostelium. Mol Biol Cell 10: 4419-4427.

ARIDOR, M. and HANNAN, L. A. (2002). Traffic jams II: an update of diseases of intracellular transport. Traffic 3: 781-790.

BAI, Y., BRUGHA, R. E., JACOBS, L., GRIGG, J., NAWROT, T. S. and NEMERY, B. (2015). Carbon loading in airway macrophages as a biomarker for individual exposure to particulate matter air pollution - A critical review. Env. Int 74: 32-41.
BAR-SAGI, D. and FERAMISCO, J. R. (1986). Induction of membrane ruffling and fluid-phase pinocytosis in quiescent fibroblasts by ras proteins. Science 233: 1061-1068.

BENNETT, N., LETOURNEUR, F., RAGNO, M. and LOUWAGIE, M. (2008). Sorting of the V-SNARE VAMP7 in Dictyostelium discoideum: A role for more than one Adaptor Protein (AP) complex. Exp. Cell Res. 314: 2822-2833.

BLOOMFIELD, G. and KAY, R. R. (2016). Uses and abuses of macropinocytosis. J Cell Sci 129: 2697-2705.

BLOOMFIELD, G., TRAYNOR, D., SANDER, S. P., VELTMAN, D. M., PACHEBAT, J. A. and KAY, R. R. (2015). Neurofibromin controls macropinocytosis and phagocytosis in Dictyostelium. Elife 4, e04940.

BOGdANOVIC, A., BENNETT, N., KIEFFER, S., LOUWAGIE, M., MORIO, T., GARIN, J., SATRE, M. AND BRUCKERT, F. (2002). Syntaxin 7, syntaxin 8, Vti1 and VAMP7 (vesicle-associated membrane protein 7) form an active SNARE complex for early macropinocytic compartment fusion in Dictyostelium discoideum. Biochem. J. 368: 29-39.

BOHDANOWICZ, M. and GRINSTEIN, S. (2013). Role of phospholipids in endocytosis, phagocytosis, and macropinocytosis. Physiol Rev 93: 69-106.

BOSMANI, C., BACH, F., LEUBA, F., HANNA, N., BURDET, F., PAGNI, M., HAGEDORN, M. and SOLDATI, T. (2019). Dictyostelium discoideum flotillin homologues are essential for phagocytosis and participate in plasma membrane recycling and lysosome biogenesis. bioRxiv 582049.

BOULAIS, J., TROST, M., LANDRY, C. R., DIECKMANN, R., LEVY, E. D., SOLDATI, T., MICHNICK, S. W., THIBAULT, P. and DESJARDINS, M. (2010). Molecular characterization of the evolution of phagosomes. Mol Syst Biol 6: 423.

BOZZARO, S. and EICHINGER, L. (2011). The professional phagocyte Dictyostelium discoideum as a model host for bacterial pathogens. Curr Drug Targets 12:942-954.

BUCKLEY, C. M. and KING, J. S. (2017). Drinking problems: mechanisms of macropinosome formation and maturation. FEBS J. 284: 3778-3790.

BUCKLEY, C. M. C. M., GOPALDASS, N., BOSMANI, C., JOHNSTON, S. A. S. A., SOLDATI, T., INSALL, R. H. R. H. and KING, J. S. (2016). WASH drives early recycling from macropinosomes and phagosomes to maintain surface phagocytic receptors. Proc. Natl. Acad. Sci. USA 113: 201524532.

BUCKLEY, C. M., HEATH, V. L., GUÉHO, A., BOSMANI, C., KNOBLOCH, P., SIKAKANA, P., PERSONNIC, N., DOVE, S. K., MICHELL, R. H., MEIER, R., et al., (2019). PIKfyve/Fab1 is required for efficient V-ATPase and hydrolase delivery to phagosomes, phagosomal killing, and restriction of Legionella infection. PLOS Pathog. 15: e1007551.

BUCZYNSKI, G., BUSH, J., ZHANG, L., RODRIGUEZ-PARIS, J. and CARDELLI, J. (1997). Evidence for a recycling role for Rab7 in regulating a late step in endocytosis and in retention of lysosomal enzymes in Dictyostelium discoideum. Mol Biol Cell 8: 1343-1360.

CARNELL, M., ZECH, T., CALAMINUS, S. D., URA, S., HAGEDORN, M., JOHNSTON, S. A., MAY, R. C., SOLDATI, T., MACHESKY, L. M. and INSALL, R. H. (2011). Actin polymerization driven by WASH causes V-ATPase retrieval and vesicle neutralization before exocytosis. J Cell Biol 193: 831-839.

CASADEVAlL, A., FU, M. S., GUIMARAES, A. J. and ALBUQUERQUE, P. (2019). The "Amoeboid Predator-Fungal Animal Virulence" Hypothesis. J Fungi 5: 10.

ChARETTE, S. J., COSSON, P., KISTLER, C., HENKEL, A. W. and SOLDATI, T. (2007). ALYST/beige homolog is involved in biogenesis of Dictyostelium secretory lysosomes. J. Cell Sci. 120: 2338-2343.

CHEN, G., ZHUCHENKO, O. and KUSPA, A. (2007). Immune-like phagocyte activity in the social amoeba. Science 317: 678-681.

CHRISTOFORIDIS, S., MCBRIDE, H. M., BURGOYNE, R. D. and ZERIAL, M. (1999a). The rab5 effector EEA1 is a core component of endosome docking. Nature 397: 621-625.

CHRISTOFORIDIS, S., MIACZYNSKA, M., ASHMAN, K., WILM, M., ZHAO, L., YIP, S.-C., WATERFIELD, M. D., BACKER, J. M. and ZERIAL, M. (1999b). Phosphatidylinositol-3-OH kinases are Rab5 effectors. Nat. Cell Biol. 1:249-252.

CLARKE, M., KÖHLER, J., ARANA, Q., LIU, T., HEUSER, J. and GERISCH, G. (2002). Dynamics of the vacuolar H+-ATPase in the contractile vacuole complex and the endosomal pathway of Dictyostelium cells. J. Cell Sci. 115: 2893-2905.

CLARKE, M., MADDERA, L., ENGEL, U. and GERISCH, G. (2010). Retrieval of the vacuolar H-ATPase from phagosomes revealed by live cell imaging. PLoS One 5: e8585.

COMMISSO, C., DAVIDSON, S. M., SOYDANER-AZELOGLU, R. G., PARKER, S. 
J., KAMPHORST, J. J., HACKETT, S., GRABOCKA, E., NOFAL, M., DREBIN, J. A., THOMPSON, C. B., et al., (2013). Macropinocytosis of protein is an amino acid supply route in Ras-transformed cells. Nature 497: 633-637.

CORNILLON, S., GEBBIE, L., BENGHEZAL, M., NAIR, P., KELLER, S., WEHRLEHALLER, B., CHARETTE, S. J., BRUCKERT, F., LETOURNEUR, F. and COSSON, P. (2006). An adhesion molecule in free-living Dictyostelium amoebae with integrin beta features. EMBO J. Rep 7: 617-621.

DERIVERY, E., SOUSA, C., GAUTIER, J. J., LOMBARD, B., LOEW, D. and GAUTREAU, A. (2009). The Arp2/3 activator WASH controls the fission of endosomes through a large multiprotein complex. Dev Cell 17: 712-723.

DIECKMANN, R., GUEHO, A., MONROY, R., RUPPERT, T., BLOOMFIELD, G. and SOLDATI, T. (2012). The balance in the delivery of ER components and the vacuolar proton pump to the phagosome depends on myosin IK in Dictyostelium. Mol Cell Proteom.11: 886-900.

DORMANN, D., WEIJER, G., DOWLER, S. and WEIJER, C. J. (2004). In vivo analysis of 3-phosphoinositide dynamics during Dictyostelium phagocytosis and chemotaxis. J Cell Sci 117: 6497-6509.

DUNN, J. D., BOSMANI, C., BARISCH, C., RAYKOV, L., LEFRANCOIS, L. H., CARDENAL-MUNOZ, E., LOPEZ-JIMENEZ, A. T. and SOLDATI, T. (2017). Eat Prey, Live: Dictyostelium discoideum As a Model for Cell-Autonomous Defenses. Front Immunol 8: 1906.

EICHINGER, I.,PACHEBAT, J. A., GLÖCKNER, G., RAJANDREAM, M. A., SUCGANG, R., BERRIMAN, M., SONG, J., OLSEN, R., SZAFRANSKI, K., XU, Q., etal., (2005). The genome of the social amoeba Dictyostelium discoideum. Nature. 435: 43-57.

FERGUSON, S. M. and DE CAMILLI, P. (2012). Dynamin, a membrane-remodelling GTPase. Nat. Rev. Mol. Cell Biol. 13, 75-88.

GHOSHAL, P., SINGLA, B., LIN, H., CHERIAN-SHAW, M., TRITZ, R., PADGETT, C. A., HUDSON, F., ZHANG, H., STANSFIELD, B. K. and CSÁNYI, G. (2019). Loss of GTPase activating protein neurofibromin stimulates paracrine cell communication via macropinocytosis. Redox Biol. 101224.

GIORGIONE, J. and CLARKE, M. (2008). Heterogeneous modes of uptake for latex beads revealed through live cell imaging of phagocytes expressing a probe for phosphatidylinositol-(3,4,5)-trisphosphate and phosphatidylinositol-(3,4)bisphosphate. Cell Motil. Cytoskeleton 65: 721-733.

GOMEZ, T. S. and BILLADEAU, D. D. (2009). A FAM21-containing WASH complex regulates retromer-dependent sorting. Dev Cell 17: 699-711.

GOPALDASS, N., PATEL, D., KRATZKE, R., DIECKMANN, R., HAUSHERR, S., HAGEDORN, M., MONROY, R., KRUGER, J., NEUHAUS, E. M., HOFFMANN, E., et al., (2012). Dynamin A, Myosin IB and Abp1 couple phagosome maturation to F-actin binding. Traffic 13: 120-130.

GOTTHARDT, D., WARNATZ, H. J., HENSCHEL, O., BRUCKERT, F., SCHLEICHER, M. and SOLDATI, T. (2002a). High-resolution dissection of phagosome maturation reveals distinct membrane trafficking phases. Mol Biol Cell 13: 3508-3520.

GOTTHARDT, D., WARNATZ, H. J., HENSCHEL, O., BRÜCKERT, F., SCHLEICHER, M. and SOLDATI, T. (2002b). High-resolution dissection of phagosome maturation reveals distinct membrane trafficking phases. Mol. Biol. Cell 13: 3508-3520.

GUEHO, A., BOSMANI, C., GOPALDASS, N., MOLLE, V., SOLDATI, T. and LETOURNEUR, F. (2016). Dictyostelium EHD associates with Dynamin and participates in phagosome maturation. J. Cell Sci. 129: 2354-2367.

HILLMANN, F., NOVOHRADSKA, S., MATTERN, D.J., FORBERGER, T., HEINEKAMP, T., WESTERMANN, M., WINCKLER, T. and BRAKHAGE, A. A. (2015). Virulence determinants of the human pathogenic fungus Aspergillus fumigatus protect against soil amoeba predation. Env. Microbiol 17: 2858-2869.

HIRST, J., SCHLACHT, A., NORCOTT, J. P., TRAYNOR, D., BLOOMFIELD, G., ANTROBUS, R., KAY, R. R., DACKS, J. B. and ROBINSON, M. S. (2014). Characterization of TSET, an ancient and widespread membrane trafficking complex. Elife 3: e02866.

HOLLIDAY, L. S., LU, M., LEE, B. S., NELSON, R. D., SOLIVAN, S., ZHANG, L. and GLUCK, S. L. (2000). The amino-terminal domain of the B subunit of vacuolar H+ATPase contains a filamentous actin binding site. J Biol Chem 275: 32331-32337.

HONG, W. (2005). SNAREs and traffic. Biochim. Biophys. Acta - Mol. Cell Res. 1744: $120-144$

HOWELL, G. J., HOLLOWAY, Z. G., COBBOLD, C., MONACO, A. P. and PONNAMBALAM, S. (2006). Cell biology of membrane trafficking in human disease. Int Rev Cytol 252: 1-69.

JENNE, N., RAUCHENBERGER, R., HACKER, U., KAST, T. and MANIAK, M. (1998).
Targeted gene disruption reveals a role for vacuolin B in the late endocytic pathway and exocytosis. J. Cell Sci. 111: 61-70.

JIA, D., GOMEZ, T. S., BILLADEAU, D. D. and ROSEN, M. K. (2012). Multiple repeat elements within the FAM21 tail link the WASH actin regulatory complex to the retromer. Mol. Biol. Cell 23: 2352-2361.

KAY, R. R., WILLIAMS, T. D. and MANTON, J. D. (2019). Living on soup : macropinocytic feeding in amoebae. Int J Dev Biol (https://doi.org/10.1387/ijdb.190220rk)

KING, J. S. (2012). Autophagy across the eukaryotes Is S. cerevisiae the odd one out? Autophagy 8: 1159-1162.

KING, J. S. and KAY, R. R. (2019). The origins and evolution of macropinocytosis. Philos Trans R Soc L. B Biol Sci 374: 20180158.

KING, J. S., GUEHO, A., HAGEDORN, M., GOPALDASS, N., LEUBA, F., SOLDATI, T. and INSALL, R. H. R. H. (2013). WASH is required for lysosomal recycling and efficient autophagic and phagocytic digestione. Mol. Biol. Cell 24: 2714-2726.

KIRKHAM, M., NIXON, S. J., HOWES, M. T., ABI-RACHED, L., WAKEHAM, D. E., HANZAL-BAYER, M., FERGUSON, C., HILL, M. M., FERNANDEZ-ROJO, M., BROWN, D. A., et al., (2008). Evolutionary analysis and molecular dissection of caveola biogenesis. J Cell Sci 121: 2075-2086.

KOLLER, B., SCHRAMM, C., SIEBERT, S., TRIEBEL, J., DELAND, E., PFEFFERKORN, A. M., RICKERTS, V. and THEWES, S. (2016). Dictyostelium discoideum as a Novel Host System to Study the Interaction between Phagocytes and Yeasts. Front Microbiol 7: 1665.

LEFKIR, Y., DE CHASSEY, B., DUBOIS, A., BOGDANOVIC, A., BRADY, R. J., DESTAING, O., BRUCKERT, F., O'HALLORAN, T. J., COSSON, P. and LETOURNEUR, F. (2003). The AP-1 clathrin-adaptor is required for lysosomal enzymes sorting and biogenesis of the contractile vacuole complex in Dictyostelium cells. Mol Biol Cell 14: 1835-1851.

LI, X., EDWARDS, M., SWANEY, K. F., SINGH, N., BHATTACHARYA, S., BORLEIS, J., LONG, Y., IGLESIAS, P. A., CHEN, J. and DEVREOTES, P. N. (2018). Mutually inhibitory Ras-PI(3,4)P 2 feedback loops mediate cell migration. Proc. Natl. Acad. Sci. USA 115: E9125-E9134.

LIM, J. J., GRINSTEIN, S. and ROTH, Z. (2017). Diversity and Versatility of Phagocytosis: Roles in Innate Immunity, Tissue Remodeling, and Homeostasis. Front Cell. Infect. Microbiol. 1: 191.

LIMA, W. C., LEUBA, F., SOLDATI, T. and COSSON, P. (2012). Mucolipin controls lysosome exocytosis in Dictyostelium. J Cell Sci 125: 2315-2322.

LIU, T., MIRSCHBERGER, C., CHOOBACK, L., ARANA, Q., SACCO, Z. D., MACWILLIAMS, H. and CLARKE, M. (2002). Altered expression of the $100 \mathrm{kDa}$ subunit of the Dictyostelium vacuolar proton pump impairs enzyme assembly, endocytic function and cytosolic pH regulation. J. Cell Sci. 109: 489-497.

LOOMIS, W. F. (2014). Cell signaling during development of dictyostelium. Dev Biol. 391: 1-16.

LOOVERS, H. M., KORTHOLT, A., DE GROOTE, H., WHITTY, L., NUSSBAUM, R L. and VAN HAASTERT, P. J. (2007). Regulation of phagocytosis in Dictyostelium by the inositol 5-phosphatase OCRL homolog Dd5P4. Traffic 8: 618-628.

LU, H. and CLARKE, M. (2005). Dynamic properties of Legionella-containing phagosomes in Dictyostelium amoebae. Cell. Microbiol. 7: 995-1007.

LUSCHER, A., FRÖHLICH, F., BARISCH, C., LITTLEWOOD, C., METCALFE, J., LEUBA, F., PALMA, A., PIRRUCCELLO, M., CESARENI, G., STAGI, M., et al., (2019). Lowe Syndrome-linked endocytic adaptors direct membrane cycling kinetics with OCRL in Dictyostelium discoideum. Mol. Biol. Cell. 30: 2268-2282.

MANIAK, M., RAUCHENBERGER, R., ALBRECHT, R., MURPHY, J. and GERISCH G. (1995). Coronin involved in phagocytosis: Dynamics of particle-induced relocalization visualized by a green fluorescent protein tag. Cell 83: 915-924.

MAYOR, S., PARTON, R. G. and DONALDSON, J. G. (2014). Clathrin-independent pathways of endocytosis. Cold Spring Harb. Perspect. Biol. 6: a016758.

MELLMAN, I. and YARDEN, Y. (2013). Endocytosis and Cancer. Cold Spring Harb Perspect Biol 5: a016949-a016949.

MERCANTI, V., CHARETTE, S. J., BENNETT, N., RYCKEWAERT, J. J., LETOURNEUR, F. and COSSON, P. (2006). Selective membrane exclusion in phagocytic and macropinocytic cups. J Cell Sci 119: 4079-4087.

MOLMERET, M., HORN, M., WAGNER, M., SANTIC, M. and KWAIK, Y. A. (2005) Amoebae as training grounds for intracellular bacterial pathogens. Appl. Environ. Microbiol. 71: 20-28.

NASSER, W., SANTHANAM, B., MIRANDA, E. R., PARIKH, A., JUNEJA, K., ROT, 
G., DINH, C., CHEN, R., ZUPAN, B., SHAULSKY, G., et al., (2013). Bacterial discrimination by dictyostelid amoebae reveals the complexity of ancient interspecies interactions. Curr Biol 23: 862-872.

NEUHAUS, E. M. and SOLDATI, T. (2000). A myosin I is involved in membrane recycling from early endosomes. J Cell Biol 150: 1013-1026.

NEUHAUS, E. M., ALMERS, W. and SOLDATI, T. (2002). Morphology and dynamics of the endocytic pathway in Dictyostelium discoideum. Mol Biol Cell 13: 1390-1407.

O'HALLORAN, T. J. and ANDERSON, R. G. (1992). Clathrin heavy chain is required for pinocytosis, the presence of large vacuoles, and development in Dictyostelium. J Cell Biol 118: 1371-1377.

O'MALLEY, M. A., WIDEMAN, J. G. and RUIZ-TRILLO, I. (2016). Losing Complexity: The Role of Simplification in Macroevolution. Trends Ecol. Evol. 31: 608-621.

PAN, M., NEILSON, M. P., GRUNFELD, A. M., CRUZ, P., WEN, X., INSALL, R. H. and JIN, T. (2018). A G-protein-coupled chemoattractant receptor recognizes lipopolysaccharide for bacterial phagocytosis. PLoS Biol 16: e2005754.

PAPAYANNOPOULOS, V. (2018). Neutrophil extracellular traps in immunity and disease. Nat. Rev. Immunol. 18: 134-147.

POUPON, V., GIRARD, M., LEGENDRE-GUILLEMIN, V., THOMAS, S., BOURBONNIERE, L., PHILIE, J., BRIGHT, N. A. and MCPHERSON, P. S. (2008). Clathrin light chains function in mannose phosphate receptor trafficking via regulation of actin assembly. Proc Natl Acad Sci U S A 105: 168-173.

RAUCHENBERGER, R., HACKER, U., MURPHY, J., NIEWÖHNER, J. and MANIAK, M. (1997). Coronin and vacuolin identify consecutive stages of a late, actin-coated endocytic compartment in Dictyostelium. Curr. Biol. 7: 215-218.

RAVANEL, K., DE CHASSEY, B., CORNILLON, S., BENGHEZAL, M., ZULIANELLO, L., GEBBIE, L., LETOURNEUR, F. and COSSON, P. (2001). Membrane sorting in the endocytic and phagocytic pathway of Dictyostelium discoideum. Eur J Cell Biol 80: 754-764.

ROELOFS, J. and VAN HAASTERT, P. J. M. (2001). Genes lost during evolution. Nature 411: 1013-1014.

RUPPER, A., GROVE, B. and CARDELLI, J. (2001). Journal of Cell Science. J. Cell Sci. 109: 1479-1495.

RUSCETTI, T., CARDELLI, J. A., NISWONGER, M. L. and O'HALLORAN, T. J. (1994). Clathrin heavy chain functions in sorting and secretion of lysosomal enzymes in Dictyostelium discoideum. J Cell Biol 126: 343-352.

SATTLER, N., BOSMANI, C., BARISCH, C., GUÉHO, A., GOPALDASS, N., DIAS, M., LEUBA, F., BRUCKERT, F., COSSON, P. and SOLDATI, T. (2018). Functions of the Dictyostelium LIMP-2 and CD36 homologues in bacteria uptake, phagolysosome biogenesis and host cell defence. J. Cell Sci. 131: jcs218040.

SEAMAN, M. N. (2012). The retromer complex - endosomal protein recycling and beyond. J Cell Sci 125: 4693-4702.

SIMONSEN, A., LIPPE, R., CHRISTOFORIDIS, S., GAULLIER, J. M., BRECH, A., CALLAGHAN, J., TOH, B. H., MURPHY, C., ZERIAL, M. and STENMARK, H. (1998). EEA1 links $\mathrm{PI}(3) \mathrm{K}$ function to Rab5 regulation of endosome fusion. Nature 394: 494-498.

SINHA, B., KÖSTER, D., RUEZ, R., GONNORD, P., BASTIANI, M., ABANKWA, D., STAN, R. V, BUTLER-BROWNE, G., VEDIE, B., JOHANNES, L., et al., (2011) Cells respond to mechanical stress by rapid disassembly of caveolae. Cell 144: 402-413.

SOUZA, G. M., MEHTA, D. P., LAMMERTZ, M., RODRIGUEZ-PARIS, J., WU, R., CARDELLI, J. A. and FREEZE, H. H. (1997). Dictyostelium lysosomal proteins with different sugar modifications sort to functionally distinct compartments. J Cell Sci. 110: 2239-2248.

STRASSMANN, J. E., ZHU, Y. and QUELLER, D. C. (2000). Altruism and social cheating in the social amoeba Dictyostelium discoideum. Nature 408: 965-967.

STUERMER, C. A. O. and PLATTNER, H. (2015). The "lipid raft" microdomain proteins reggie-1 and reggie-2 (flotillins) are scaffolds for protein interaction and signalling. Biochem. Soc. Symp. 72: 109-118.

SUSSMAN, R. and SUSSMAN, M. (1967). Cultivation of Dictyostelium discoideum in axenic medium. Biochem. Biophys. Res. Commun. 72: 109-118.

VELTMAN, D. M., AUCIELLO, G., SPENCE, H. J., MACHESKY, L. M., RAPPOPORT, J. Z. and INSALL, R. H. (2011). Functional analysis of Dictyostelium IBARa reveals a conserved role of the I-BAR domain in endocytosis. Biochem $J$ 436: 45-52.

VIEIRA, O. V., BOTELHO, R. J., RAMEH, L., BRACHMANN, S. M., MATSUO, T., DAVIDSON, H. W., SCHREIBER, A., BACKER, J. M., CANTLEY, L. C. and GRINSTEIN, S. (2001). Distinct roles of class I and class III phosphatidylinositol 3-kinases in phagosome formation and maturation. J. Cell Biol. 155: 19-26.

VITAVSKA, O., WIECZOREK, H. and MERZENDORFER, H. (2003). A novel role for subunit $\mathrm{C}$ in mediating binding of the H+-V-ATPase to the actin cytoskeleton. $\mathrm{J}$. Biol. Chem. 278: 18499-18505.

WANG, X., HUANG, T., BU, G. J. and XU, H. X. (2014). Dysregulation of protein trafficking in neurodegeneration. Mol. Neurodegener. 9: 1-9.

WATKINS, R. A., ANDREWS, A., WYNN, C., BARISCH, C., KING, J. S. and JOHNSTON, S.A. (2018). Cryptococcus neoformans escape from Dictyostelium amoeba by both WASH-mediated constitutive exocytosis and vomocytosis. Front. Cell. Infect. Microbiol. 8: 108

WATTS, D. J. and ASHWORTH, J. M. (1970). Growth of myxameobae of the cellular slime mould Dictyostelium discoideum in axenic culture. Biochem J119:171-174.

WEINBERG, J. and DRUBIN, D. G. (2012). Clathrin-mediated endocytosis in budding yeast. Trends Cell Biol. 22: 1-13.

WESSELS, D., REYNOLDS, J., JOHNSON, O., VOSS, E., BURNS, R., DANIELS, K., GARRARD, E., O'HALLORAN, T. J. and SOLL, D. R. (2000). Clathrin plays a novel role in the regulation of cell polarity, pseudopod formation, uropod stability and motility in Dictyostelium. J Cell Sci 113: 21-36.

WIENKE, D. C., KNETSCH, M. L., NEUHAUS, E. M., REEDY, M. C. and MANSTEIN, D. J. (1999). Disruption of a dynamin homologue affects endocytosis, organelle morphology, and cytokinesis in Dictyostelium discoideum. MolBiol Cell10:225-243.

WILLIAMS, T. D. and KAY, R. R. (2018). The physiological regulation of macropinocytosis during Dictyostelium growth and development. J. Cell Sci. 131: jcs213736.

WILLIAMS, T. D., PASCHKE, P. I. and KAY, R. R. (2019). Function of small GTPases in Dictyostelium macropinocytosis. Philos. Trans. R. Soc. BBiol. Sci. 374: 20180150

XU, G. F., OCONNELL, P., VISKOCHIL, D., CAWTHON, R., ROBERTSON, M., CULVER, M., DUNN, D., STEVENS, J., GESTELAND, R., WHITE, R., et al., (1990). The Neurofibromatosis Type-1 Gene Encodes a Protein Related to Gap. Cell 62: 599-608.

ZHANG, J., REILING, C., REINECKE, J. B., PRISLAN, I., MARKY, L. A., SORGEN, P. L., NASLAVSKY, N. and CAPLAN, S. (2012). Rabankyrin-5 Interacts with EHD1 and Vps26 to Regulate Endocytic Trafficking and Retromer Function. Traffic. 13: 745-757.

ZHANG, X., ZHUCHENKO, O., KUSPA, A. and SOLDATI, T. (2016). Social amoebae trap and kill bacteria by casting DNA nets. Nat. Commun. 7: 10938. 


\section{Further Related Reading, published previously in the Int. J. Dev. Biol.}

YelA, a putative Dictyostelium translational regulator, acts as antagonist of DIF-1 signaling to control cell-type proportioning Yoko Yamada, Chris Sugden and Jeffrey G. Williams

Int. J. Dev. Biol. (2017) 61: 35-42

https://doi.org/10.1387/ijdb.160160yy

Dictyostelium discoideum Sir2D modulates cell-type specific gene expression and is involved in autophagy

Rakhee Lohia, Punita Jain, Mukul Jain, Pradeep Kumar Burma, Anju Shrivastava and Shweta Saran

Int. J. Dev. Biol. (2017) 61: 95-104

https://doi.org/10.1387/ijdb.160038ss

The Dictyostelium prestalk inducer DIF-1 directs phosphorylation of a bZIP transcription factor

Yoko Yamada, Yuzuru Kubohara, Haruhisa Kikuchi, Yoshiteru Oshima, Hong-Yu Wang, Susan

Ross and Jeffrey G. Williams

Int. J. Dev. Biol. (2013) 57: 375-381

https://doi.org/10.1387/ijdb.130046jw

Bimodal distribution of motility and cell fate in Dictyostelium discoideum

Pavana Goury-Sistla, Vidyanand Nanjundiah and Gopal Pande

Int. J. Dev. Biol. (2012) 56: 263-272

https://doi.org/10.1387/ijdb.113384ps

Identification of a target for CudA, the transcription factor which directs formation of the Dictyostelium tip organiser

Hong-Yu Wang and Jeffrey G. Williams

Int. J. Dev. Biol. (2010) 54: 161-165

https://doi.org/10.1387/ijdb.082723hw

Pattern formation mechanisms in reaction-diffusion systems

Vladimir K. Vanag and Irving R. Epstein

Int. J. Dev. Biol. (2009) 53: 673-681

https://doi.org/10.1387/ijdb.072484vv

Cell cycle phase, cellular Ca2+ and development in Dictyostelium discoideum MAzhar, P KKennady, G Pande, M Espiritu, WHolloman, D Brazill, R H Gomer and V Nanjundiah Int. J. Dev. Biol. (2001) 45: 405-414

http://www.intjdevbiol.com/web/paper/1133086
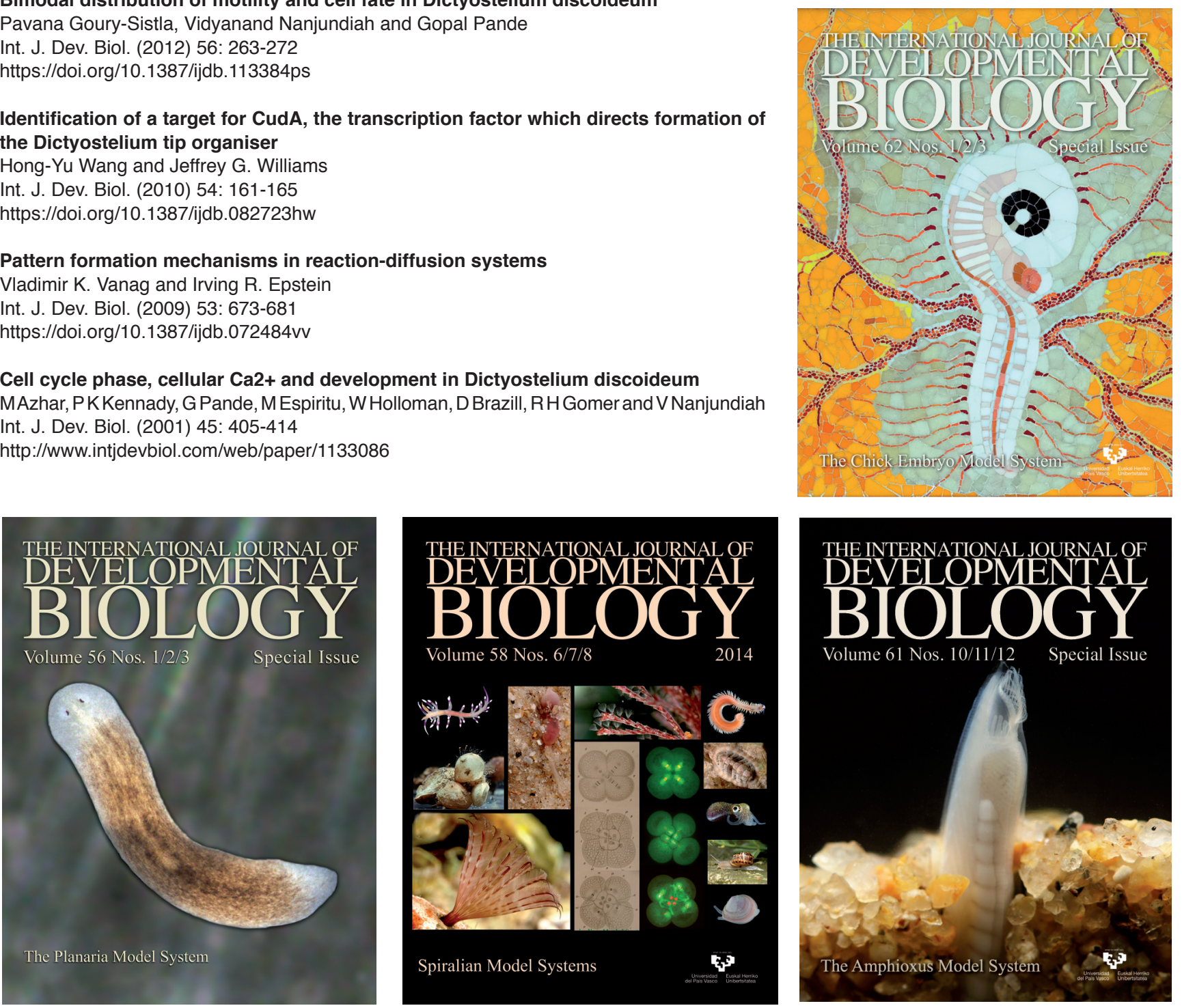